\title{
Control of ovarian follicular development to the gonadotrophin-dependent phase: a 2006 perspective
}

\author{
KP MCNatty ${ }^{\top}, K$ Reader $^{2}$, P Smith ${ }^{2}$, DA Heath ${ }^{2}$ and IL Juengel ${ }^{2}$ \\ 1 School of Biological Sciences, Victoria University of Wellington, Wellington, New Zealand \& \\ 2AgResearch, Wallaceville Animal Research Centre, Upper Hutt, New Zealand
}

In sheep, as in other mammals, ovarian follicular growth is regulated mainly by intraovarian growth factors during early development with pituitary hormones increasingly important during the final phases to ovulation. Most follicles are present as primordial structures and these express many hundreds of genes that fulfil an array of housekeeping and signalling functions. Once growth has been initiated, at least two oocyte-derived growth factors, namely growth differentiation factor 9 (GDF9) and bone morphogenetic protein 15 (BMP15), are critical for ongoing development to ovulation, most likely by regulating the proliferative and differentiative functions of adjacent follicular cells. In sheep, the granulosa cell populations double some 12-14 times and a well-defined thecal layer differentiates before antrum formation and the time taken to complete this process varies between 50-150 days with very little follicular atresia. During preantral growth, FSH and $\mathrm{LH}$ receptors coupled to the cyclic AMP second messenger system develop in granulosa and thecal cells respectively. From the late preantral stage, GDF9, BMP15 and perhaps other factors are thought to regulate gene expression in cumulus cells to enhance metabolic cooperativity with the oocyte and in mural granulosa cells to regulate their responses to pituitary hormones. In sheep, antral follicular development is characterized by a much faster rate of growth, additional increases in the numbers of granulosa (4-5 more doublings) and thecal cells, an increased level of steroid and inhibin secretion in response to $\mathrm{FSH}$ and $\mathrm{LH}$, but also by most follicles undergoing atresia. The final number of follicles that go on to ovulate is dependent upon FSH as well as the intrafollicular concentrations of GDF9 and BMP15.

\section{Introduction}

In ruminants and other mammals, the initiation of ovarian follicular growth begins in late fetal or early neonatal life and continues without interruption throughout infancy, the oestrous cycle, pregnancy, lactation and regardless of ageing. Moreover, most stages of follicular growth (thal is, $>80 \%$ of development) occur independently of the day of the oestrous cycle, reproductive 
status and age of the animal: these early stages of growth are considered to be gonadotrophinindependent and then gonadotrophin-responsive with pituitary hormones not considered to be essential (Scaramuzzi et al. 1993; McNatty et al. 2006). Indeed, it is only the final stages of development to ovulation, when follicles are critically dependent upon moment-by-moment gonadotrophic support. From gene-knockout studies in mice and naturally-occurring mutations and physiological studies in sheep, it is now evident that most stages of follicular development are regulated by factors within the ovary at a paracrine or perhaps autocrine level (Shimasaki et al. 2004; McNatty et al. 2006). In this context, it is now known that the oocyte plays a central role in orchestrating the growth of the follicle by regulating the expression of genes in the adjacent granulosa cells (Sugiura \& Eppig 2005). In turn, it is thought that granulosa cells differentiate into two phenotypes namely the cumulus and mural granulosa cells and that these cell-types develop different functional roles as the follicle matures (Sugiura et al. 2005). The purpose of this review, using the ewe as the ruminant model, is to examine the evidence for local control, the role of pituitary hormones and to describe what is known about the stage specific expression of genes considered to be important during the gonadotrophin-independent and-responsive phases of follicular development.

\section{Early follicular growth: current concepts}

\section{The primordial follicle}

In the ewe, primordial follicles first form around day 75 of fetal life with the maximum numbers present between days 100 and 120 of gestation (Smith et al. 1993; 1994; Sawyer et al. 2002). With increasing age, the number of primordial follicles declines progressively. At 120 and 135 days of fetal life, 4 weeks of postnatal life, and 2, 5 and 6 years of age, the respective mean (and 95\% confidence limits) numbers of primordial follicles are $100,000(80,000,160,000)$, $87,000(67,000,111,000), 70,000(51,000,86,000), 59,000(52,000,67,000), 20,000(11,000$, 36,000) and 16,000 (11,000, 21,000) (Smith et al, 1994; McNatty et al. 2001). While accurate numbers of primordial follicles in old age ewes are not available, there are numerous records of ewes still producing off-spring at 14 years suggesting that this species does not run out of follicles during their lifetime.

In sheep, the very-slow growing primordial follicle (Type 1; Fig. 1) contains between 3 and 52 granulosa cells (mean $=16$ cells) and an oocyte between 23 and $52 \mu \mathrm{m}$ in diameter (mean $=35 \mu \mathrm{m}$ ) (Lundy et al. 1999). Little, if any, atresia of primordial follicles occurs (Cahill, 1981). Approximately 2500 expressed sequence tags from Type 1 follicles have been matched to around 500 mRNAs linked to cytoskeletal events, DNA repair and mRNA processing, ribosomal function, protein synthesis and ubiquitination, and signalling pathways (D.A. Heath, J.L. Juengel \& K.P. McNatty, unpublished data). Immunohistochemical localisation of connexins 37 and 43 suggests that there are contacts, albeit limited, between the oocyte and granulosa cells (Fig. 1: Grazul-Bilska et al. 1997). Oocytes in primordial follicles express mRNAs and proteins for c-kit, oestradiol receptor beta (ERß) and certain bone morphogenetic protein (BMP) and transforming growth factor beta (TGFB) receptors and binding proteins (betaglycan) (Fig. 2: Tisdall et al. 1999; Juengel et al. 2004; Juengel \& McNatty 2005; Juengel et al. 2006a,b). In addition, oocytes express mRNAs for at least two growth factors, namely BMP6 and growth differentiating factor 9 (GDF9) with immunohistochemical evidence for the presence of GDF9 protein. Since GDF9 is also expressed in germ cells before and during follicular formation as well as in primordial and developing follicles, it seems likely that it fulfils some housekeeping roles although these have not been determined. Granulosa cells in primordial follicles synthesize stem cell factor (SCF) mRNA and protein, have the ability to metabolise progesterone and 
potentially respond to ligands that bind to Type 1 TGFß and/or Type II BMP receptors (Fig. 2).
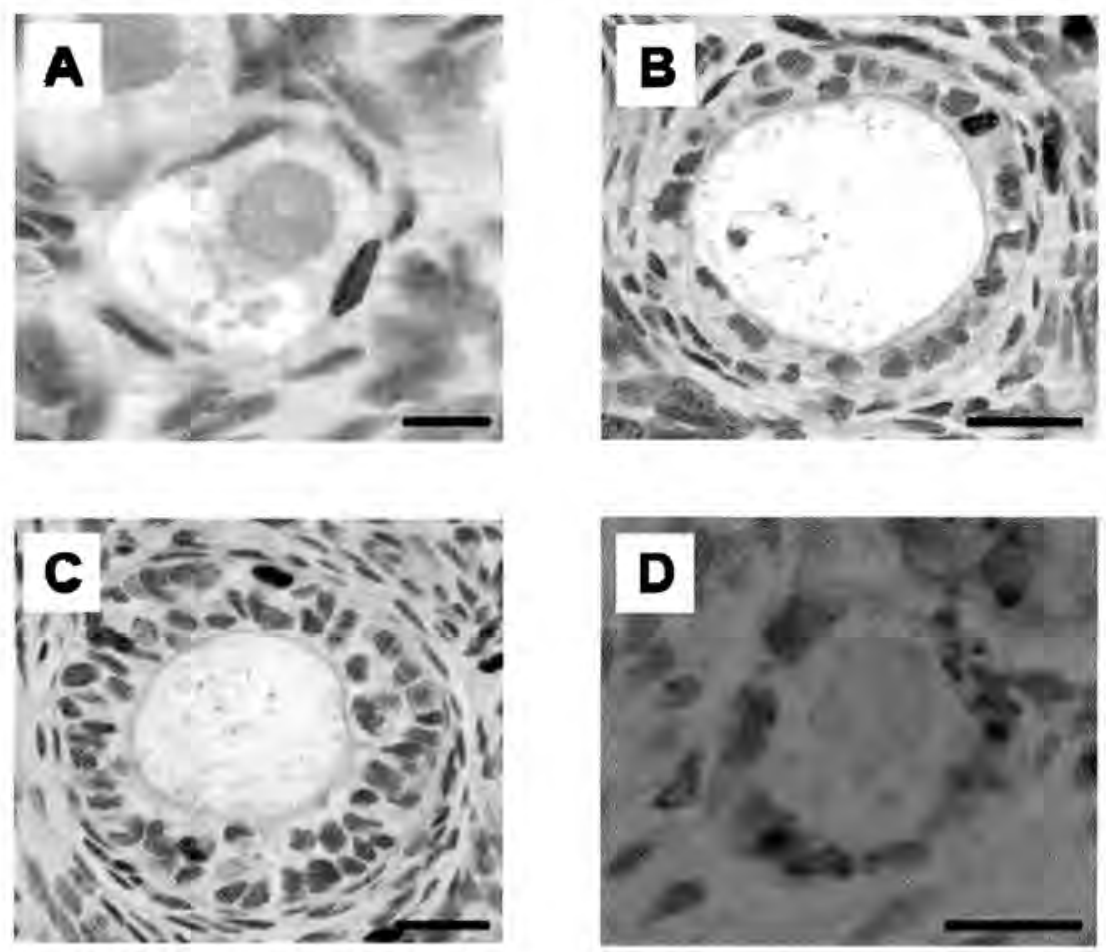

Fig. 1. Evidence for cell proliferation in early developing follicles and cell-cell contacts as determined by BrdU labelling in granulosa cells of a primordial (Type 1; A), primary (Type $2 ; \mathrm{B}$ ) and a secondary (Type 3; C) follicle and connexin 37 immunostaining in a Type 1 follicle (D). The immunohistochemical procedures used for BrdU are described by Sawyer et al. (2002) and for connexin 37 by Logan et al. (2003). The connexin 37 antibody was an affinity purified rabbit anti-mouse preparation (Alpha Diagnostics, San Antonio, $\mathrm{Tx}$ ). The BrdU- and connexin-labelled cells are stained brown. Scale bars are 10 $\mu \mathrm{m}$ (A), $20 \mu \mathrm{m}(\mathrm{B}), 25 \mu \mathrm{m}(\mathrm{C})$ and $20 \mu \mathrm{m}(\mathrm{D})$.

Collectively, the evidence suggests that the primordial follicle has some awareness of its microenvironment and that it is expressing many hundreds of genes to fulfil an array of housekeeping and signalling functions.

\section{The primordial to primary follicular growth transition}

In the ewe, the primary follicle contains between 30 and 520 granulosa cells (mean $=128$ cells) and an oocyte between 31 and $81 \mu \mathrm{m}$ in diameter (mean $=52 \mu \mathrm{m}$ ) (Lundy et al. 1999). During this aspect of growth, the granulosa cells all become cuboidal in appearance and the population undergoes 1-2 doublings with a concomitant enlargement in the diameter of the oocyte (Figs. 1 \& 2). The molecular signals which initiate the entry of a primordial or transitory (that is, Type 1or $1 \mathrm{a}$ ) follicle into the primary and preantral stages of development are uncertain but may involve multiple factors both stimulatory and inhibitory. What is clear is that this early growth phase does not involve pituitary hormones as there are no $\mathrm{FSH}$ receptors present on 


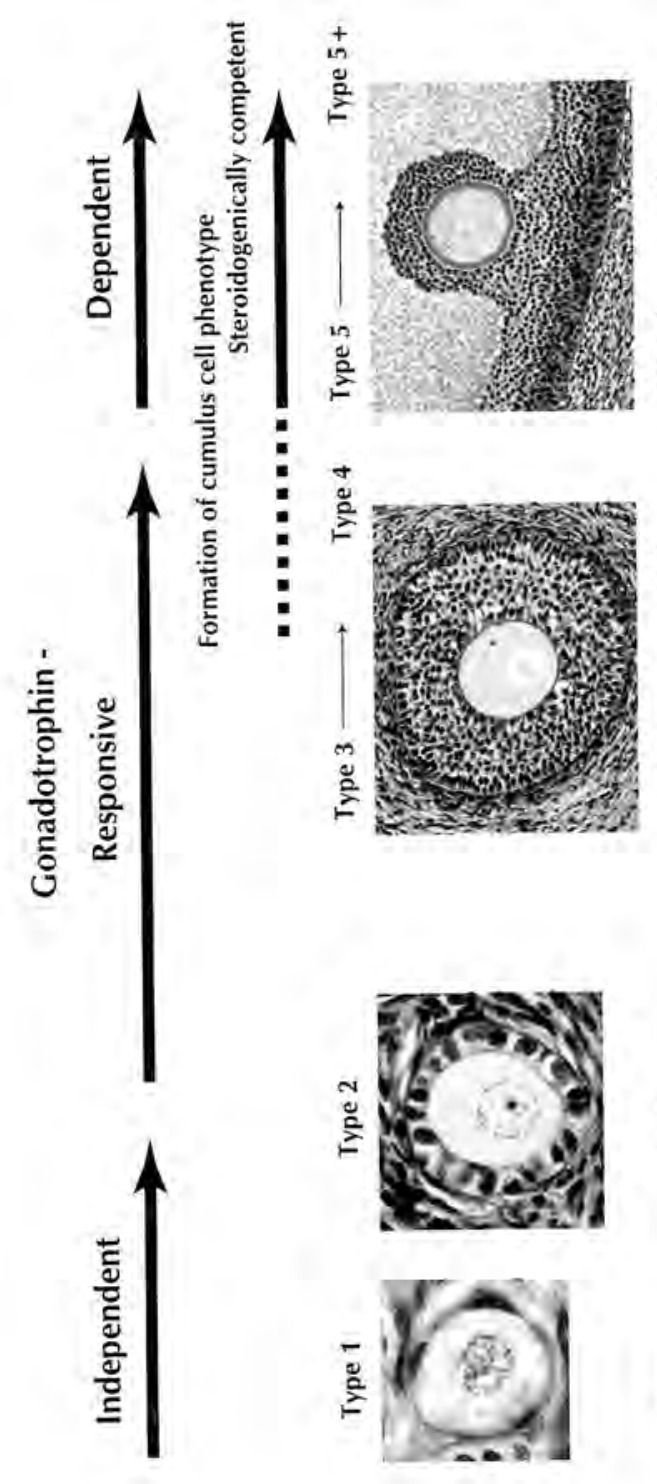

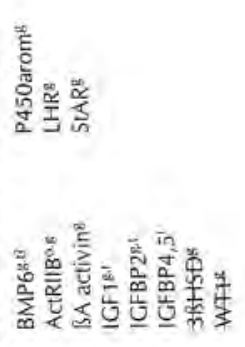

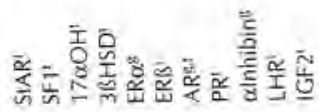

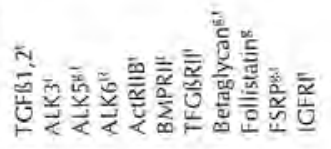

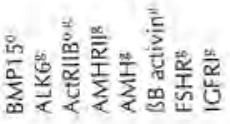

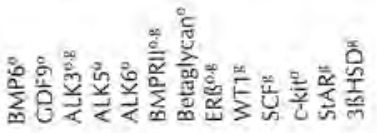

\section{$\frac{\mathrm{e}}{\mathrm{E}}$}

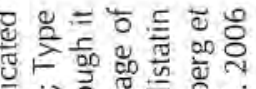

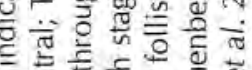

는

들

乡ह है

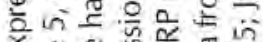

㐅े

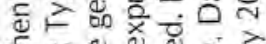

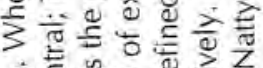

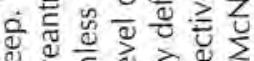

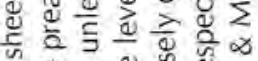

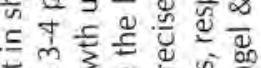

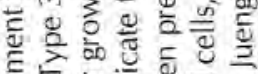

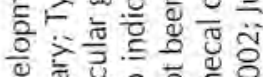

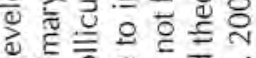

흔용

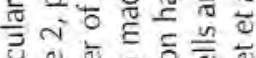

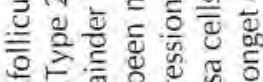

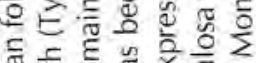

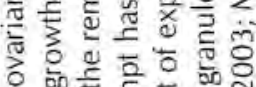

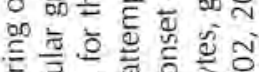

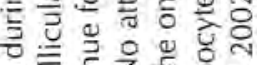

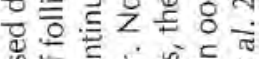

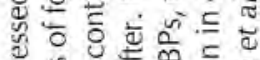

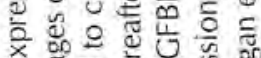

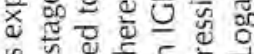

ڤ

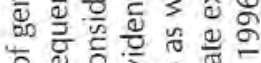

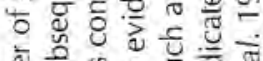

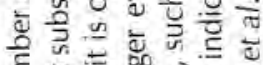

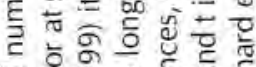

¿

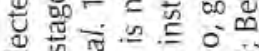

ज

त

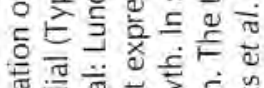

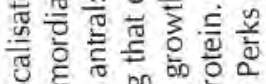

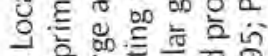

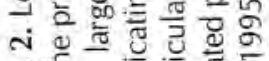

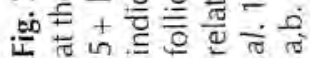


granulosa cells until primary follicles are formed and LH receptors on thecal cells are only evident when this cell-type differentiates in secondary follicles (Fig. 2). Moreover, hypophysectomy does not inhibit this phase of growth (Dufour et al. 1979). Neither GDF9 nor BMP15 are likely to be involved in the early phases of this growth initiation since in vivo immunoneutralisation studies in the ewe show that the formation of primary follicles is not inhibited (Juengel et al. 2002) although the mean oocyte diameters are significantly larger than in the controls during the transition (Type 1a follicles) or when primary follicles are formed (Type 2). It should also be noted that BMP15 is not present in oocytes until the Type 1a or 2 stage of growth (Fig. 2). From studies in rodents, leukaemia inhibitory factor (LIF), basic fibroblast growth factor (bFGF), stem cell factor, insulin, BMP4, BMP7 and keratinocyte growth factor (KGF) have all been implicated as potential growth initiating factors (Skinner 2005). In the ewe, BMP 4 and 7 mRNA (as well as BMP 2 mRNA) were not found in non-atretic ovarian follicles although BMP4 mRNA was identified in cells of the surface epithelium and around blood vessels (Juengel et al. 2006a). Basic FGF protein has been localised to primordial follicles in the cow (van Wezel et al. 1995) but was not found to be stimulatory to bovine primordial follicles in vitro (Derrar et al. 2000). In the ovine ovary, the onset of expression and cellular location of bFGF, LIF or KGF are not known.

With respect to inhibitory factors, the evidence in mice is that anti-Müllerian hormone $(\mathrm{AMH})$ and stromal derived factor-1 (SDF-1) have been shown to inhibit the formation of primary follicles (Durlinger et al. 2002; Holt et al. 2006). In the ewe, the onset of expression of $\mathrm{AMH}$ and the AMH Type II receptor is exclusive to granulosa cells at the primary (Type 2) stage (Fig. 2) but that for SDF-1 or its putative receptor, CXCR4, is not known. The molecular mechanism as to how AMH inhibits follicular growth is also unclear. Although the Type II receptor in sheep has been identified, evidence for the identity of the Type I receptor in the ovary remains to be established.

Skinner (2005) has proposed, on the basis of studies in rodents, that a key factor in the transformation of a primordial follicle to the primary stage of growth involves recruitment of thecal cells from precursors in the adjacent stroma/interstitium and that granulosa cell and oocyte signalling molecules (for example, bFGF and SCF) are involved. In turn, thecal/ stromal-derived factors such as KGF together with systemically-derived insulin may act on adjacent granulosa cells to initiate or advance development to the primary stage. This hypothesis is testable in ruminants but the experiments remain to be undertaken. Cultures of isolated or pooled populations of ovine primordial follicles using a variety of culture methodologies for up to 20 days in vitro in the presence or absence of isolated stroma/interstitial cells, fetal calf serum and additives such as insulin, IGF-1 and oestradiol have not been successful in stimulating the transformation of a primordial to a primary follicle (Fig. 1). By contrast, the culture of ovarian cortical explants from cow, baboon or human ovaries resulted in an unexpectedly large number of flattened granulosa cells in primordial follicles transforming into cuboidal cells and undergoing proliferation. However, growth was abnormal and there was no associated enlargement of the oocyte (reviewed by Braw-Tal 2002),

Collectively, these data are consistent with the hypothesis proposed by Skinner (2005) that the transformation of a primordial follicle into a primary follicle is the result of a communication exchange between the follicle and the adjacent stromal/interstitial and perhaps endothelial cells involving both inhibitory and stimulatory signalling pathways.

The primary to large preantral growth phase

A large preantral follicle in the ewe contains between 1090 and 3404 granulosa cells (mean = 
2104 cells) and an oocyte between 71 and $120 \mu \mathrm{m}$ in diameter (mean $=88 \mu \mathrm{m}$ ) (Lundy et al. 1999). Thus, from the primary stage, a further 6 doublings of the granulosa cell population and a 1.7-fold increase in the diameter of the oocyte takes place before a large preantral follicle is formed (Figs. 1 \& 2). As follicles grow from the primary stage, the onset of expression of many more genes occurs in a stage and cell-specific manner (Fig. 2). From the primary stage, there is evidence for the continued expression in oocytes of BMP6 and GDF9 but also of BMP15, the Type IIB activin and BMPII receptors, and the Type 1 receptors ALK 3,5 and 6 as well as c-kit (Fig. 2). Granulosa cells develop the potential to synthesize inhibin and follistatin, become responsive to steroids via receptors for androgen and oestradiol, and develop type II receptors for activin and the Type I receptors ALK 5 and 6 . The theca cells develop a receptivity to progestins, androgens, oestradiol, activin, TGFßs, and BMPs and also the ability to synthesize TGFB 1 and 2, progestins and androgens (Fig. 2). Importantly, granulosa cells develop receptors to FSH and theca cells to $\mathrm{LH}$ and under in vitro conditions, large preantral follicles respond to $\mathrm{LH}$ and $\mathrm{FSH}$ to synthesize CAMP and thereafter, in small antral follicles to synthesize progestins and androgens (McNatty et al. 1999). In pituitary-intact ewes, the level of follicular atresia in preantral follicles is very low (Cahill 1989). Moreover, after hypophysectomy, there is also no increase in the prevalence of atresia of preantral follicles in the short-term. However, after long-term hypophysectomy that is, $>60$ days) an increase in atresia was observed (Dufour et al. 1979) but the total number of follicles up to $2-3 \mathrm{~mm}$ in diameter remained unchanged and no difference was noted in vitro in the numbers of responsive follicles with respect to gonadotrophin-induced cAMP synthesis (McNatty et al. 1990a). From the late preantral phase through to ovulation, it is evident, at least in mono-ovulatory species such as sheep and humans, that follicles develop in a hierarchical manner and that few, if any, are at the same stage of development at any moment in time (McNatty et al. 1999). In the ewe, this pattern of hierarchical development is unaffected by hypophysectomy (McNatty et al. 1999). Moreover, ovulation can be induced in chronically hypophysectomised ewes or hypothalamic-pituitary disconnected ewes following a short-term treatment with pregnant mares serum gonadotrophin (PMSG) and human chorionic gonadotrophin (Fry et al. 1988) or with exogenous gonadotrophin-releasing hormone $(\mathrm{GnRH})$ pulses, PMSG and a $\mathrm{GnRH}$ bolus regimen (McNatty et al. 1993b). However, it is not known whether the ovulated oocytes are capable of fertilisation and development into viable embryos.

Collectively, the evidence suggests that the growth of follicles through the preantral stages is not critically dependent on threshold concentrations or short-term fluctuations of pituitary hormones.

\section{Intraovarian control of preantral follicular growth}

In mice lacking a functional GDF9 gene, normal follicular development was arrested shortly after primordial follicles had started to grow with evidence of continued enlargement of the oocyte but without a concomitant increase in the numbers of granulosa cells (Dong et al.1996). This study demonstrated for the first time that an oocyte-derived factor was essential for normal follicular development. Animals homozygous for the GDF9 inactivation were sterile whereas the heterozygous knockouts showed a normal phenotype. Subsequent studies with mice lacking other growth factors produced by oocytes, such as BMP6 (Solloway et al. 1998) and BMP15 (Yan et al. 2001), were fertile although a modest reduction in fertility was evident in the homozygous BMP1 5 knockouts. In the ewe, a number of naturally-occurring genetic mutations have been identified in either GDF9 or BMP15 which affect fertility although no mutations have been identified for BMP6 (Galloway et al. 2000; Bodin et al. 2003; Hanrahan et al. 2004). 
In the ewe, as in mice, GDF9 and BMP15 are expressed exclusively within the ovary by oocytes (Fig. 2). For GDF9, one mutation has been identified in the mature region of the protein and the resulting homozygous mutant phenotype is sterile whereas the heterozygous phenotype has an increased ovulation rate around $87 \%$ above that of the wild-type (Hanrahan et al. 2004). For BMP15, five different point mutations have been identified, with 4 in the mature region and one in the proregion of the protein with the resulting homozygous mutant phenotypes being sterile. In 4 of the heterozygous phenotypes that have been studied, a 35 $95 \%$ increase in ovulation rate was observed compared to the respective wild-types (reviewed by McNatty et al. 2006). Of interest is the finding that animals that were heterozygous for mutations in both GDF9 and BMP15 had ovulation rates that were at least additive to those for each mutation separately (McNatty et al. 2006). In women with unexplained infertility, 4 heterozygous point mutations have now been identified in the proregion of BMP15 (Di Pasquale et al. 2004, 2006) and at least one of these heterozygous mutant forms of BMP15 has been shown in vitro to be a competitive antagonist to the wild-type protein with respect to its actions on granulosa cells.

Immunisation of ewes at monthly intervals with 15-16 mer $\mathrm{N}$-terminal peptides of GDF9 or BMP15 conjugated to keyhole limpet haemocyanin $(\mathrm{KLH})$ generated strong immune responses. In this study, antisera raised against GDF9 did not cross-react with BMP15 and vice versa (Juengel et al. 2002). None of the KLH control immunised ewes had antibodies to GDF9 or BMP15 and all continued to show regular oestrous cycles. In contrast most of the GDF9 (8/9) and BMP15 (9/10) immunised animals became anovulatory with normal ovarian follicular activity being disrupted at the primary follicular stage. The ovarian phenotype was similar to that observed in the homozygous GDF9 knockout mice and homozygous GDF9 and BMP15 mutant ewes. The ovaries at recovery were significantly smaller after the GDF9 and BMP15 treatments compared to the controls but no differences between the groups were noted in the mean numbers of primordial follicles. At the transitory (Type 1a) and primary stages of growth, oocyte diameters were significantly larger after the BMP15 and GDF9 immunisations, respectively, and by the late preantral stage of growth, the numbers of follicles were significantly reduced in both of these groups compared to the controls.

In ewes, a naturally-occurring mutation in the BMP Type I receptor, ALK6, has also been found to have a profound effect on early follicular development and ovulation rate (Mulsant et al. 2001; Souza et al. 2001; Wilson et al. 2001). Animals heterozygous and homozygous for this mutation have ovulation rates around $76 \%$ and $130 \%$ higher respectively than the wildtypes (McNatty et al. 2006). The effect of the ALK6 mutation is observed from the primary stage of growth onwards when the diameter of the oocyte is noticeably larger than in the equivalent-sized wild-type follicles throughout preantral follicular growth. The consequence was that in the homozygous ALK6 mutants, the oocyte reached around $130 \mu \mathrm{m}$ in a large preantral follicle whereas in the wild-type this diameter was not reached until the early antral stage. Unlike in the BMP15 and GDF9 mutants, there was a concomitant increase in granulosa cell number with oocyte growth. However, by the early antral stage, the numbers were significantly lower in the ALK6 mutants compared to the wild-types. Moreover, there was an earlier onset of maturation of the follicle in the ALK6 mutants and they ovulated at smaller diameters than in the wild-types (Montgomery et al. 2001; Wilson et al. 2001). In essence, in the ALK6 mutants, the granulosa cells undergo 1-2 less doublings and during early antral development, the granulosa cells enter a differentiative pathway earlier than in the wild-types. Interestingly, when heterozygous ALK6 mutant animals were mated with heterozygous BMP15 mutants (FecXI), the effect on ovulation rate was greater than additive for the two mutations (Davis et al. 1999) suggesting a level of co-operativity between BMP15 and the Type I receptor. In these 
animals, it would be of interest to examine the interrelationships among oocyte diameters, granulosa cell populations and diameters of the follicles at ovulation.

Collectively, the in vivo evidence in ewes shows that GDF9 and BMP15 are essential regulators of preantral follicular development and that a functional relationship exists between BMP15 and ALK6 and also between BMP15 and GDF9. Whether a similar relationship exists between GDF9 and ALK6 is not known. In mice, GDF9 but not BMP15 is essential for early follicular growth; whereas in humans, BMP15 is essential but the role for GDF9 remains to be determined. The evidence suggests there are species differences with respect to the onset of gene expression for GDF9, BMP15 and other BMPs, as well as differences in how oocytederived growth factors influence follicular development and ovulation rate.

\section{Development from a large preantral to a gonadotrophin-dependent follicle}

In the ewe, an ovarian follicle becomes gonadotrophin-dependent upon reaching around $3 \mathrm{~mm}$ in diameter. Thus, the population of granulosa cells is required to double around 8 times from the large preantral stage (McNatty et al. 1990a; Lundy et al. 1999). During this growth phase an increasing proportion of granulosa cells transform from a mainly proliferating state to a differentiating one (Monniaux et al. 1994). Moreover, during this period, follicles are still developing in a hierarchical manner and no two follicles share a common hormonal microenvirironment at any moment in time. Also, during this interval, a significant number of follicles (that is, $>30$ $80 \%$ ) are lost by atresia (McNatty et al.1984). The number of non-atretic follicles that develop to around $3 \mathrm{~mm}$ in diameter in sheep is highly variable (that is, between 1 and 25) and dependent upon genotype, time of the oestrous cycle and time of year (McNatty et al. 1984; 1985 , 2001). However, the number of non-atretic follicles $\geq 3 \mathrm{~mm}$ in diameter can be enhanced by long-term (that is several days), exogenous FSH treatment (McNatty et al. 1993a) and this occurs without changing the total population of antral follicles ( $\geq 1 \mathrm{~mm}$ in diameter). Thus, FSH is able to influence the proportion of ovulatory follicles by preventing atresia of small antral follicles but not by 'speeding-up' the number of preantral or very small antral follicles growing $\geq 1 \mathrm{~mm}$ in diameter. The growth of a follicle from the primary to the preantral stage varies from around 25 days in fetal life to many months in adult life (Smith et al.1993; 1994; Turnbull et al. 1977). However, the growth of antral follicles from around $1 \mathrm{~mm}$ in diameter to ovulation is more rapid and can take as little as three days (Cahill 1981; Tsonis et al. 1984). This variable rate of growth is likely to be influenced by serum-derived as well as local ovarian-derived growth factors such as the availability of IGF1, GDF9 and BMP15 (Juengel et al. 2002; Monget et al. 2002). In the ewe, under in vitro conditions, IGF1 stimulated proliferation of granulosa cells from follicles $\leq 3 \mathrm{~mm}$ in diameter. In vivo, this enhanced rate of proliferation is associated with a significant decline in the local follicular fluid levels of IGFBP-2 and -4 most likely due, in part, to a decrease in mRNA expression and an increase in protease activity (Monget et al. 2002). As follicles develop to $3 \mathrm{~mm}$ in diameter, the granulosa cells become increasingly responsive to FSH-induced cyclic AMP synthesis reflecting the increased differentiative capacity of the cells. This increase is not due to a change in the number of FSH receptors or binding affinity but to a decrease in CAMP-dependent phosphodiesterase activity, increased bio-availability of IGF1 and a marked increase in adenylate cyclase activity (McNatty et al, 1990b; Monget et al. 2002).

Intraovarian control of antral follicular growth

Recently, Sugiura \& Eppig (2005) have proposed that GDF9 and perhaps other oocyte-derived 
factors play a role in determining the cumulus and mural granulosa phenotypes during the preantral to early antral phase of growth. These authors report that oocytes control the level of cellular metabolism in cumulus cells by regulating the expression of genes involved in events such as amino-acid transport and glycolysis. In turn, this localised upregulation of gene expression, which is not observed in the mural granulosa cells, leads to an enhanced level of metabolic co-operativity between the oocyte and cumulus cells. In the bovine ovary, there is evidence of a localised concentration gradient of BMPs from the oocyte across the cumulus cells inferring that these cells are likely to be exposed to higher concentrations than the more distant mural granulosa cells (Fig 3: Hussein et al. 2005). In ovine follicular fluid, both GDF9 and BMP15 have been detected as promature but not as cleaved mature proteins and the presence of BMP6 and other BMPs have yet to be confirmed (McNatty et al. 2006). Irrespective of the forms of GDF9 or BMP15 in follicular fluid, passive immunisation of ewes with GDF9 or BMP15 antisera at the onset of luteolysis inhibited normal follicular growth, ovulation and/or corpus luteum function (Juengel et al. 2002). While there are marked increases in connexins and junctional communication between the oocyte and granulosa/cumulus cells during follicular growth, more information on the importance of the somatic cells to the oocyte during the preantral to antral follicular transition as well as on the utilisation of serum-derived nutrients or other factors is required.

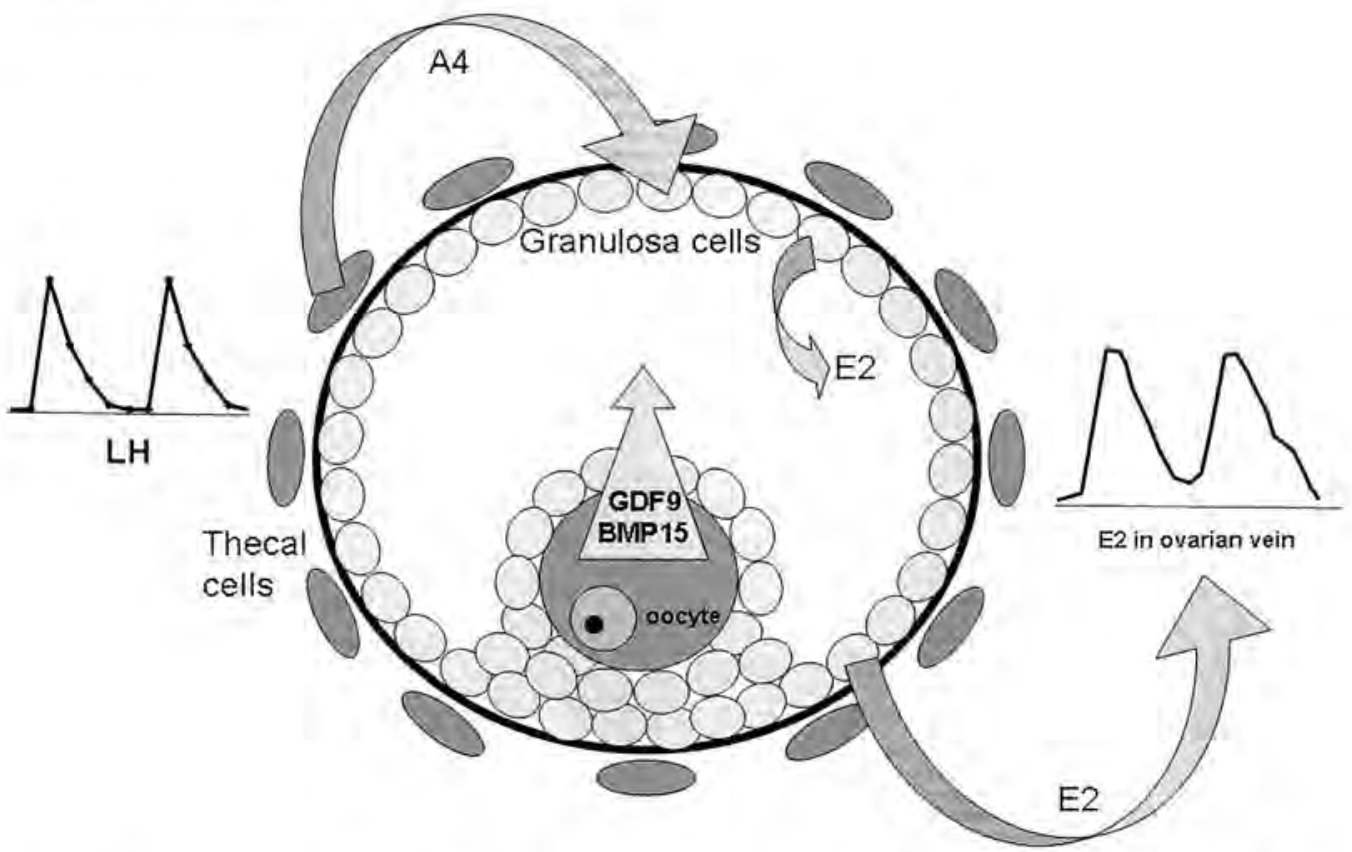

Fig. 3. Schematic outline of a gonadotrophic-responsive and steroidogenically active follicle. In response to $\mathrm{LH}$ pulses, androstenedione (A4) is produced by thecal cells and metabolised by granulosa cells to oestradiol (E2) with most of the E2 secreted without accumulating within the follicle. However, the steroid concentration within the follicle is not fluctuant but changes slowly compared to that entering the ovarian vein (McNatty et al. 1981). It is likely that a concentration gradient of oocyte-derived BMP15 and GDF9 exists within the follicle with the cumulus cells exposed to higher concentrations than the mural granulosa cells. It is also likely that both BMP15 and GDF9 continue to be important during the follicular phase of the oestrous cycle in ewes since passive immunisation with anti-BMP15 or-GDF9 inhibits ovulation or normal corpus luteum function (Juengel et al. 2002). 
There are extensive reports of the roles of BMPs on granulosa and thecal cells from antral follicles in vitro (reviewed by: Matzuk et al. 2002; Knight \& Glister 2003; Shimasaki et al. 2004; Juengel \& MCNatty 2005). It is important to note that the pattern and onset of ligand expression of the TGFB-superfamily during follicular growth is not identical across species (see Erickson \& Shimasaki 2003; Knight \& Glister 2003; Juengel \& McNatty 2005; Juengel et al. 2006a). In rat granulosa cells, GDF9, BMP15 and BMP6 inhibit LHR, FSHR and StAR and p450scc mRNA, respectively. Thus the in vitro evidence suggests that GDF9 and BMP15 influence the responsiveness of mural granulosa cells to pituitary hormones and this is supported by in vivo results in the ewe (reviewed by: Shimasaki et al. 2004; McNatty et al. 2006). In the ewe, cow and rat, GDF9 and BMP15 when added together, often act co-operatively to enhance the proliferation of granulosa cells and to suppress progesterone production in vitro (McNatty et al. 2006). Together these ligands act via the BMP Type II receptor to affect granulosa cell function. In sheep, thecal cells in both preantral and small antral follicles have a number of Type I and II BMP and TGFß receptors (Fig. 2) and thus the potential to respond to activin, TGFB and BMP ligands. However, the issue arises as to the range of ligands that might be available locally to influence follicular growth. In the ewe, TGFB1 and 2 mRNA have been localised to thecal cells, BMP6 to oocytes at all stages of growth and possibly to the granulosa cells from the early antral development (Juengel et al. 2006a). Activin together with inhibin and follistatin is likely to be of granulosa cell origin (Fig. 2). Of the other possible ligands, BMP4 mRNA has been identified around blood vessels in the thecal region (Juengel et al. 2006a). In bovine thecal cells, BMP 4 and 6 suppressed both basal and LH induced androgen but not progesterone production (Glister et al. 2005).

Collectively therefore, the responsiveness of granulosa and thecal cells to gonadotrophins is likely to be modulated by locally produced members of the TGFß superfamily. In turn, this is likely to influence the level of hormonal interaction of the developing follicle with the extraovarian endocrine system as the follicle progresses from the preantral phase of growth.

\section{The gonadotrophin-dependent follicle}

The granulosa cells in ovarian follicles at $3 \mathrm{~mm}$ in diameter have a capacity to synthesize inhibin, follistatin and $\mathrm{AMH}$ and have a FSH-responsive adenylate cyclase system, but they still require the acquisition of the $\mathrm{P} 450$ aromatase enzyme and a $\mathrm{LH}$ receptor coupled to adenylate cyclase before developing the ability to become the dominant follicle within the ovary. With respect to thecal cells, the $\mathrm{LH}$-induced output of androstenedione increases during antral follicular growth but the increase is thought to be related to an increasing population of cells rather than to an increased output per cell (McNatty et al. 1984). During the transition to dependence upon gonadotrophins, the capacity of granulosa cells adjacent to the basement membrane to metabolise steroid substrate (that is, androstenedione) from LH-stimulated thecal cells increases. Once granulosa cells acquire aromatase activity, a very significant proportion (that is, $>90 \%$ ) of the oestradiol produced within $30 \mathrm{~min}$ of an $\mathrm{LH}$ pulse is exported to the ovarian vein without first accumulating in follicular fluid (Fig. 3: McNatty et al. 1981). In contrast, the transit time of LH and probably FSH entering follicular fluid is slow (that is, hours) as is the accumulation of steroid (McNatty et al.1981). Therefore, it is unlikely that the cumulus cells would be exposed to short-term fluctuations in gonadotrophins or steroids. Nevertheless, most serum-derived molecules are present in follicular fluid so that the oocyte-cumulus cell complexes are exposed to extra-ovarian as well as local follicular factors. 


\section{Conclusions}

Over the past decade new insights have been gained into how ovarian follicles form and develop to ovulation. Arguably, the greatest advances have come through the identification of some of the intra-ovarian factors through the inactivation of target genes in mice (Anreu-Vieyra et al. 2006). Related studies with naturally-occurring mutations in sheep have also helped in providing new information on oocyte-derived growth factors and their effects on both follicular development and ovulation rate. It is clear that the oocyte is a major source of growth factors influencing follicular development, the phenotypes of the granulosa and cumulus cells and the responsiveness of granulosa and perhaps thecal cells to gonadotrophins. Several major challenges still remain including an understanding of how primordial follicles initiate their transformation to a primary follicle, the extent of the signalling and metabolic interactions between the oocyte and adjacent granulosa/cumulus cells, and the key factors that regulate the rate at which follicles may grow.

\section{Acknowledgements}

The authors thank their colleagues in the Reproductive Biology team at the Wallaceville Animal Research Centre for their technical and scientific input and especially Dr Doug Eckery for advice during preparation of the manuscript. Funding support was provided by the New Zealand Foundation for Research Science and Technology and the Marsden Fund.

\section{References}

Andreu-Vieyra C, Lin YN \& Matzuk MM 2006 Mining the oocyte transcriptome. Trends in Endocrinology and Metabolism 17 136-143.

Bodin L, Lecerf F, Pisselet C, San Cristhal M, Bibe M \& Mulsant P 2003 How many mutations are associated with increased ovulation rate and litter size in progeny of Lacaune meat sheep. In Proceedings of the International Workshop on Major Genes and QTL in Sheep and Goat, pp 2-11. Publisher INRA, Toulouse, France.

Besnard N, Pisselet C, Monniaux D, Locatelli A, Benne F, Gasser F, Hatey F \& Monget P 1996 Expression of messenger ribonucleic acids of insulin-like growth factor binding proteins-2, -4 , and -5 in the ovine ovary: localization and changes during growth and atresia of antral follicles. Biology of Reproduction 55 1356-1367.

Braw-Tal R 2002 The initiation of follicle growth: the oocyfe or the somatic cells? Molecular and Cellular Endocrinology 187 11-18.

Cabill LP 1981 Folliculogenesis in the sheep as influenced by breed, season and oestrous cycle. Journal of Reproduction and Fertility Supplement 30 135142

Davis GH, Dodds KG \& Bruce GD 1999 Combined effect of the Inverdale and Booroola prolificacy genes on ovulation rates. Proceedings of the Association for the Advancement of Animal Breeding Genetics 14 175-178.

Derrar N, Price CA \& Sirard MA 2000 Effect of growth factors and co-culture with avarian medulla on the activation of primordial follicles in explants of bovine ovarian cortex. Theriogenology $\mathbf{5 4}$ 587-598.

Di Pasquale E, Beck-Peccoz P \& Personi L 2004 Hypergonadotropic ovarian failure associated with an inherited mutation of human bone morphogenetic protein-15 (BMP15). American Journal of Human Genetics 75 106-111.

Di Pasquale E, Rossetti R, Marozzi A, Bodega B, Borgato S, Cavallo L, Einaudi S, Radetti G, Russo G, Sacco M, Wasniewska M, Cole T, Beck-Peccoz P, Nelson LM \& Persani L 2006 Identification of new variants of human BMP15 gene in a large cohort of women with premature ovarian failure. Journal of Clinical Endocrinology and Metabolism 91 1976-1979.

Dong J, Albertini DF, Nishimori K, Rajenda Kumar T, Lu N \& Matzuk MM 1996 Growth differentiation factor 9 is required for early ovarian folliculogenesis. Nature 383 531-535.

Dufour J, Cahill LP \& Mauleon P 1979 Short- and longterm hypophysectomy and unilateral ovariectomy on ovarian follicular populations in sheep. Journal of Reproduction and Fertility 57 301-309.

Durlinger AL, Gruijters MJ, Kramer P, Karels B, Ingraham HA, Nachtigal MW, Uilenbroek JT, Grootegoed JA \& Themmen APN 2002 Anti-Mullerian hormone inhibits initiation of primordial growth in the mouse ovary. Endocrinology 143 1076-1084 Erickson GF \& Shimasaki S 2003 The spatiotemporal 
expression pattern of the bone morphogenetic protein family in rat ovary cell types during the estrous cycle. Reproductive Biology and Endocrinology 1 9.

Fry RC, Clarke IJ, Cummins IT, Bindon BM, Piper LR \& Cahill LP 1988 Induction of ovulation in chronically hypophysectomised Booroola ewes, Journal of Reproduction and Fertility 82 711-715.

Galloway SM, MCNatty KP, Cambridge LM, Laitinen MPE, Juengel JJ, Jokiranta TS, McLaren RJ, Luiro K, Dodds KG, Montgomery GW, Beattie AE, Davis GH \& Ritvos O 2000 Mutations in an oocyte-derived growth factor (BMP15) cause increased ovulation rate and infertility in a dosage-sensitive manner. Nature Genetics 25 279-283.

Glister C, Richards SL \& Knight PG 2005 Bone morphogenetic proteins (BMP)-4, 6, and -7 potently suppress basal and luteinising hormone-induced androgen production by bovine theca interna cells in primary culture: could ovarian hyperandrogenic dysfunction be caused by a defect in thecal BMP signalling? Endocrinology 146 1883-1892.

Grazul-Bilska AT, Reynolds LP \& Redmer DA 1997 Gap junctions in the ovaries. Biology of Reproduclion $57947-957$.

Hanrahan JP, Gregan SM, Mulsant P, Mullen M, Davis GH, Powell R \& Galloway SM 2004 Mutations in the genes for oocyte-derived growth factors GDF9 and BMP15 are associated with both increased ovulation rate and sterility in Cambridge and Belclare sheep (Ovis Aries). Biology of Reproduction 70 900909.

Holt JE, Jackson A, Roman SD, Aitken RJ, Koopman P \& McLaughlin EA 2006 CXCR4/SDF1 interaction inhibits the primordial to primary follicle transition in the neonatal mouse ovary. Developmental Biology 293 449-460.

Hussein TS, Froiland DA, Amato F, Thompson JG \& Gilchrist RB 2005 Oocytes prevent cumulus cell apoptosis by maintaining a morphogenic paracrine gradient of bone morphogenetic proteins. Journal of Cell Science 118 5257-5268.

Juengel IL \& MCNatty KP 2005. The role of proteins of the transforming growth factor-beta superfamily in the intraovarian regulation of follicular development. Human Reproduction Update 11 143-160.

Juengel JL, Hudson NL, Heath DA, Smith P, Reader $K L$, Lawrence SB, $O^{\prime}$ Connell AR, Laitinen MP, Cranfield M, Groome NP, Ritvos O \& McNatty KP 2002 Growth differentiation factor 9 and bone morphogenetic protein 15 are essential for ovarian follicular development in sheep. Biology of Reproduction 67 1777-1789

Juengel JL, Bibby AH, Reader KL, Lun S, Quirke LJ, Haydon LJ \& McNatty KP 2004 The role of transforming growth factor-beta (TGF-beta) during ovarian follicular development in sheep. Reproductive Biology and Endocrinology 278.

Juengel JL, Reader KL, Bibby AH, Lun S, Ross I, Haydon L. \& McNatty KP 2006a The role of bone morpho- genetic proteins $2,4,6$ and 7 during ovarian follicular development in sheep: contrast to rat, Reproduction 131 501-513.

Juengel JL, Heath DA, Quirke LD \& McNatty KP 2006b Oestrogen receptor $\alpha$ and $\beta$, androgen receptor and progesterone receptor $\mathrm{mRNA}$ and protein localisation within the developing ovary and in small growing follicles of sheep. Reproduction 131 81-92.

Knight PG \& Glister C 2003 Local roles of TGF-beta superfamily members in the control of ovarian follicle development. Animal Reproduction Science 78 165-183.

Leeuenberg BR, Hurst PR \& McNatty KP 1995 Expression of IGF-I mRNA in the ovine ovary. lournal of Endocrinology 15 251-258.

Logan KA, Juengel JL \& McNatty KP 2002 Oriset of steroidogenic enzyme gene expression during ovarian follicular development in sheep. Biology of Reproduction 66 906-916.

Logan KA, McNatty KP \& Juengel JL 2003 Expression of Wilms' tumor gene and protein localization during ovarian follicular development in sheep. Biology of Reproduction 68 635-643.

Lundy T, Smith P, O'Connell A., Hudson N L \& McNatty KP 1999 Populations of granulosa cells in small follicles of the sheep. Journal of Reproduction and Fertility 115 251-262.

McNatty KP, Dobson C, Gibb M, Kieboom L \& Thurley DC 1981 Accumulation of luteinising hormone, oestradiol and androstenedione by sheep ovarian follicles in vivo. Journal of Endocrinology 9199. 109.

McNatty KP, Hudson NL, Henderson KM, Lun S, Heath DA, Gibb M, Ball K, McDiarmid JM \& Thurley DC 1984 Changes in gonadotrophin secretion and ovarian follicular activity in seasonally breeding sheep throughout the year. Journal of Reproduction and Fertility 70 309-321.

McNatty KP, Hudson NL, Gibb M, Ball K, Henderson KM, Heath DA, Lun S \& Kieboom LE 1985 FSH influences follicle viability, oestradiol biosynthesis and ovulation rate in ewes. Journal of Reproduction and Fertility 75 121-131.

McNatty KP, Heath DA, Hudson NL \& Clarke IJ 1990a Effect of long-term hypophysectomy on ovarian follicle populations and gonadotrophin-induced adenosine 3,5 monophosphate output by follicles from Booroola ewes with or without the $F$ gene. Journal of Reproduction and Fertility 90 515-522.

McNatty KP, Lun S, Hudson NL \& Forbes S 1990b Effects of follicle stimulating hormone, cholera toxin, pertusis toxin and forskolin on adenosine 3,5-monophosphate output by granulosa cells from Booroola ewes with or without the F gene. Journal of Reproduction and Fertility 89 553-563.

McNatty KP, Hudson NL, Heath DA, Shaw L, Blay L, Berry L \& Lun S 1993a Effect of chronic FSH administration on ovarian follicular development, ovulation rate and corpora lutea formation in sheep. Journal of Endocrinology 138 315-324 
McNatty KP, Hudson NL, Lun S, Heath DA, Shaw L, Condell L, Phillips DJ \& Clarke IJ 1993b Gonadotrophin-releasing hormone and the control of ovulation rate by the FecB gene in Booroola ewes. Journal of Reproduction and Fertility 98 97-105.

McNatty KP, Heath DA, Lundy $I$, Fidler AE, Quirke L, O'Connell, A, Smith P, Groome N \& Tisdall DJ 1999 Control of early ovarian follicular development. Journal of Reproduction and Fertility Supplement 54 3-16.

McNatty KP, Juengel JL, Wilson T, Galloway SM \& Davis GH 2001 Genetic mutations influencing ovulation rate in sheep. Reproduction, Fertility and Development 13 549-555.

McNatty KP, Lawrence S, Groome NP, Meerasahib MF, Hudson NL, Whiting L, Heath DA \& Juengel JL 2006 Oocyte signalling molecules and their effects on reproduction in ruminants. Reproduction, Fertility and Development 18 403-412.

Matzuk MM, Burns KH, Viveiros MM \& Eppig IJ 2002 Intercellular communication in the mammalian ovary: oocytes carry the conversation. Science $2962178-$ 80.

Monget $P$, Fabre $S$, Mulsant $P$, Lecerf $F$, Elsen JM, Mazerbourg S, Pisselet C \& Monniaux D 2002 Regulation of ovarian folliculogenesis by IGF and BMP system in domestic animals. Domestic Animal Endocrinology 23 139-154.

Monniaux D, Pisselet C \& Fontaine J 1994 Uncoupling between proliferation and differentiation of ovine granulosa cells in vitro. Journal of Endocrinology 142 497-510.

Montgomery GW, Galloway SM, Davis GH \& McNatty KP 2001 Genes controlling ovulation rate in sheep. Reproduction 121 843-852.

Mulsant P, Lecerf F, Fabre S, Schibler L, Monget $P$, Lanneluc I, Pisselet C, Riquet J, Monniaux D, Callebaut I, Cribiu E, Thimonier J, Bodin L, Cognie Y, Chitour N \& Elsen JM 2001 Mutation in bone morphogenetic protein receptor-1B is associaled with increased ovulation in Booroola ewes. Proceedings of the National Academy of Sciences USA 98 5104-5109.

Perks CM, Denning-Kendall PA, Gilmore RS \& Wathes DC 1995 Localization of messenger ribonucleic acids for insulin-like growth factor 1 (IGF-1), IGF-11 and the Type I IGF receptor in the ovine ovary throughout the oestrous cycle. Endocrinology 1365266 5273.

Sawyer HR, Smith P, Heath DA, Juengel JL, Wakefield SJ \& MCNatty KP 2002 Formation of ovarian follicles during fetal development in sheep. Biology of Reproduction 66 1134-1150.

Scaramuzzi RJ, Adams NR, Baird DT, Campbell BK, Downing JA, Findlay JK, Henderson KM, Martin GB, McNatty KP, McNeilly AS \& Tsonis CG 1993 A model for follicle selection and the determination of ovulation rate in the ewe. Reproduction, Fertility and Development 5 459-478

Skinner MK 2005 Regulation of primordial follicle as- sembly and development. Human Reproduction Update 11 461-471.

Shimasaki S, Moore RK, Otsuka F \& Erickson GF 2004 The bone morphogenetic protein system in mammalian reproduction. Endocrine Reviews 25 72-101.

Smith P, O W-S, Hudson NL, Shaw L, Heath DA, Condell L, Phillips DJ \& McNatty KP 1993 Effects of the Booroola gene (FecB) on body weight, ovarian development and hormone concentrations during fetal life. Journal of Reproduction and Fertility $\mathbf{9 8}$ 41-54.

Smith P, Braw-Tal R, Corrigan K, Hudson NL, Heath DA \& McNatty KP 1994 Ontogeny of ovarian rollicle development in Booroola sheep fetuses that are homozygous carriers or non-carriers of the FecB gene. Journal of Reproduction and Fertility 100 485490.

Solloway MJ, Dudley AT, Bikoff EK, Lyons KM, Hogan BL \& Robertson EJ 1998 Mice lacking Bmp6 function. Developmental Cenetics 22 321-339.

Souza CJH, MacDougall, C, Campbell BK, MCNeilly AS \& Baird DT 2001. The Booroola (FecB) phenotype is associated with a mutation in the bone morphogenetic receptor type IB (BMPRIB) gene. loutnal of Endocrinology 169 R1-R6.

Sugiura K \& Eppig JJ 2005 Control of metabolic cooperativity between oocytes and their companion granulosa cells by mouse oocytes. Reproduction, Fertility and Development 17 667-674.

Sugiura K, Pendola FL, Eppig JI 2005 Oocyte control of metabolic cooperativity between oocytes and companion granulosa cells: energy metabolism. Developmental Biology 279 20-30.

Tisdall DJ, Fidler AE, Smith P, Quirke LD, Stent VC, Heath DA \& MCNatty KP 1999 Stem cell factor and $c$-kit gene expression and protein localization in the sheep ovary during fetal development. Journal of Reproduction and Fertility 116 277-291.

Tsonis CG, Cahill LP, Carson RS \& Findlay JK 1984 Identification at the onset of luteolysis of follicles capable of ovulation in the ewe Journal of Reproduction and Fertility 70 609-614.

Turnbull KE, Braden AWH \& Mattner PE 1977. The pattern of follicular growth and atresia in the ovine ovary. Australian lournal of Biological Science $\mathbf{3 0}$ 229-241.

van Wezel IL, Umapathysivam K, Tilley WD \& Rodgers R) 1995 Immunohistochemical localization of basic fibroblast growth factor in bovine ovarian follicles. Molecular and Cellular Endocrinology 115 133-140.

Wilson T,Wu XY, Juengel JL, Ross IK, Lumsden JM, Lord EA, Dodds KG, Walling GA, McEwan JC, O'Connell AR, MCNatty KP \& Montgomery GW 2001 Highly prolific Booroola sheep have a mutation in the intracellular kinase domain of bone morphogenetic protein IB receptor (ALK-6) that is expressed in both oocytes and granulosa cells. Biology of Reproduction 64 1225-1235.

Yan C, Wang P, De Mayo J, De Mayo FJ, Elvin JA, Carino C, Prasad SV, Skinner SS, Dunbar BS, Dube 
IL, Celeste AJ \& Matzuk MM 2001. Synergistic roles of bone morphogenetic protein 15 and growth differentiation factor 9 in ovarian function. Molecular Endocrinalogy 15 854-866. 